\title{
Editorial
}

A Revista Brasileira de Cirurgia Cardiovascular/Brazilian Journal of Cardiovascular Surgery (RBCCV/BJCVS) foi recentemente incluída pelo Scielo em um grupo de 15 revistas nacionais selecionadas pela entidade com a finalidade de serem avaliadas pelo ISI, importante base de dados internacional na área da saúde. Publicamos, abaixo, no original em inglês, a carta e os principais trechos do dossiê elaborado pelo coordenador geral do Scielo, Prof. Dr. Rogério Meneghini, e do coordenador operacional da mesma instituição, Dr. Abel Packer, para apresentar a nossa revista ao ISI.

Domingo M. Braile

Editor

RBCCV/BJCVS

\section{Dossier of the Brazilian Journal "Revista Brasileira de Cirurgia Cardiovascular" (Brazilian Journal of Cardiovascular Surgery) Submitted to the Journal of Citation Report/ISI, Aimed at Indexation on JCR.}

\author{
Rogerio MENEGHINI ${ }^{1}$, Abel PACKER ${ }^{2}$
}

Major Remarks

$\mathrm{T}$ his is a submission to ISI aimed at the indexing of "Revista Brasileira de Cirurgia Cardiovascular" (Brazilian Journal of Cardiovascular Surgery) to the Journal of Citation Report. In the appendix we provide a reasonable amount of information and data confirming the statements given here and stressing the appropriateness of this request. The international editorial board is one of them, which warrants an inclination to the acceptance of articles of broad interest and not those of regional significance only. The members of the editorial board have published an average of 24.8 articles in ISI-indexed journals, a significant figure in this area.

Cardiology is a strong area of medicine and scientific research in Brazil. The professionals of this area are very active in scientific activities as may be inferred from their participation in international congresses and publications in international journals. Revista Brasileira de Cirurgia Cardiovascular is far from being the only channel of written scientific communication used by Brazilian scientists in this area. Instead, it corresponds to an effort to close a cycle of scientific activities: to face the challenges of making a journal that publishes a share of the scientific results of Brazilian scientists and that is aimed at attracting the interest of the international community as both readers and potential authors.

Also interesting to point out is the frequency with which the authors of this journal publish in ISI-indexed journal. As an example, of the 217 authors of the 43 articles published in 2001, $47 \%$ have published in ISIindexed journals, with an average of 6.47 articles per author. This is a significant figure given the fact that in this area many publications are in proceedings of congresses or book chapters.

The site of the journal was visited 13,776 times in 2002. In the same year article requests reached the impressive number of 16,912. These numbers can be accessed at the Scielo Site (www.scielo.br) where the most requested articles can also be envisaged.

All original articles and case reports are always published in English as full texts in the electronic version.

The rejection rate has also increased in recent years and in 2002 attained $36.7 \%$. 
A final data is worth to be presented. If one examines the 2001 science edition of the Journal of Citation Reports, one finds 65 journals listed, under the category of Cardiac \& Vascular Systems. Of these, 5 (7.7\%) had impact factors about the same than that of Revista Brasileira de Cirurgia Cardiovascular (0.136).

It is in no doubt that indexing of Revista Brasileira de Cirurgia Cardiovascular in ISI database would provide a much a higher visibility to this journal and, in this case, it is likely that its impact factor would reach a position above $20 \%$ of journals in this category.

Acknowledgement: We would like to express our gratitude to Adalberto O. Tardelli, Rogerio Magnaini, Rosely de Fátima Pellizzon, Regina Castro, Márcia Barreto and Andrea Cristina F. do Carmo for their help in obtaining the data.

\section{APENDIX}

Dossier of the Brazilian Journal "Revista Brasileira de Cirurgia Cardiovascular" (Brazilian Journal of Cardiovascular Surgery) Submitted to the Journal of Citation Report/ISI, Aimed at Indexation on JCR.

\section{Basic Information}

The journal is the official publication of the Rev. Bras. Cir. Cardiovasc. Its aim is to publish representative works related to the cardiovascular surgery, including original papers, research results, actualizations, case reports, as well as papers presented at the Congresses of the Society. Its abbreviated title is Rev. Bras. Cir. Cardiovasc., which should be used in bibliographies, footnotes and bibliographical references and strips. From 1992 up to the present it has been published quarterly and ever since 1986 without interruption. The Rev. Bras. Cir.Cardiovasc. is sponsored both by the Sociedade Brasileira de Cirurgia Cardiovascular and by the National Council of Science and Technology of Brazil.

\section{Features of the Revista Brasileira de Cirurgia Cardiovascular}

Cardiovascular surgery is a strong area of medicine and scientific research in Brazil. The members of the Society are very active in scientific activities as may be inferred from their participation in international congresses and publications in international journals. Rev. Bras. Cir. Cardiovasc. is far from being the only channel of written scientific communication used by Brazilian scientists in this area. Instead, it corresponds to an effort to close a cycle of scientific activities: to face the challenges of making a journal that publishes a share of the scientific results of Brazilian scientists and that is aimed at attracting the interest of the international community as readers and potential authors.

\section{Indexing Sources}

The journal is indexed by SciELO, Lilacs and Index
Medicus Latino-Americano.

\section{Downloading of Articles}

Full text articles can be downloaded from SciELO database (http://www.scielo.br), both in HTML and PDF.

\section{Language}

Articles should be written in Portuguese (in the current spelling) and in English. The translation into English will be published wholly in the Scielo site (www.scielo.br) staying "on line" at the disposal of the international community with specific links in the organization's site in Brazil and in site entered at CTSNET (www.ctsnet.org) in the United States of America.

\section{Country Origin of the Articles}

Almost all articles from 2002 (49) were from Brazilian Institutions, only one of them being in collaboration with a French group. From the last 2002 issue on, publication of all articles in English became mandatory. It is likely that this policy will call the attention of other countries authors upon this journal in order to publish their articles there.

\section{Editorial Board}

The Editorial Board is comprised by 40 Editors from which only three are not from Brazil. The international interest of the articles would recommend an internationally more representative Editorial Board. Even more so if we consider that these editors have published 1067 articles in many different ISI journals of the area, representing an average of 26.7 articles per editor. Anyway, this fact reassures that the review of articles will be carried out under an attempt to offer the readers not only articles with a regional importance,

\section{Peer Review and Rejection Rate}

All manuscripts sent to this journal are submitted for evaluation by at least three peer reviewers selected from the associated editors and members of the editorial council. In 2002, 62 articles were submitted of which 40 were accepted. Therefore the rejection rate has been $36.7 \%$.

\section{Bibliometric Data}

Bibiometric data are currently used as an important complementary platform to examine the status of a given scientific journal. SciELO has adopted a procedure for this objective that essentially follows the ISI methodology. Table 1 shows that the Impact Factor of this Journal in 2001 was 0.136 and was achieved with citations given only by SciELO journals, basically by the Rev. Bras. Cir. Cardiovasc. itself. However, from 1991 to 2001, this journal received 60 citations from ISI journals, according to a search carried out by ISI, under a contract between ISI and SciELO.

Clearly, this Journal has a potential to increase its Impact Factor, should it be indexed in ISI database. It would not be exaggerated to expect that, shortly after ISI indexing, its Impact Factor would reach around 0.5. 
If one examines the 2001 science edition of the Journal of Citation Reports, one finds 65 journals listed under the category of Cardiac and Cardiovascular Systems. Of these, 5 (7.7\%) had impact factors about the same of that of Rev. Bras. Cir. Cardiovasc. (0.136). It is in no doubt that indexing of Rev. Bras. Cir. Cardiovasc. in ISI database would provide this journal with a much higher visibility and, in this case, it is likely that its impact factor would reach a position above $20 \%$ of journals in this category.

\section{Rev. Bras. Cir. Cardiovasc. Citing Pattern}

Table 2 shows how Rev. Bras. Cir. Cardiovasc.cited itself and other journals in 2001. Only journals cited more than 20 times are shown. This helps to realize the range of interest of this journal' authors, in the international versus national context. In 2001, ISI journals were cited 497 times and SciELO journals were cited 49 times by Rev. Bras. Cir. Cardiovasc., considering a sample of the most cited journals. The only SciELO journal cited by Rev. Bras. Cir. Cardiovasc. was itself. At any rate, the interest of the authors in subjects published in international journals becomes well documented.

\section{Authors of Articles}

There were 217 authors in the 43 articles published by in 2001. These authors have published all together 1405 articles in ISI-indexed journal. The average number of
Table 1. Impact Factor, Immediacy Index and Half Life as measured by using SciELO database.

\begin{tabular}{|c|c|c|c|c|c|c|c|c|c|c|}
\hline \multicolumn{11}{|c|}{ SciELO journal: REVISTA BRASILEIRA DE CIRURGIA CARDIOVASCULAR Year: 2001} \\
\hline \multicolumn{5}{|c|}{ Scielo Citations to Rev Bras Cir Cardiovasc: } & \multicolumn{3}{|c|}{ 1999:9 } & \multicolumn{3}{|c|}{$2000: 3$} \\
\hline \multicolumn{5}{|c|}{ Number of Articles published by Rev Bras Cir Cardiovasc: } & \multicolumn{3}{|c|}{ 1999: 46} & \multicolumn{3}{|c|}{$2000: 42$} \\
\hline \multicolumn{5}{|c|}{ Impact Factor } & \multicolumn{3}{|c|}{$(9+3) /(46+42)=$} & \multicolumn{3}{|c|}{0.1364} \\
\hline \multicolumn{5}{|c|}{ Scielo Citations to Rev Bras Cir Cardiovasc: } & \multicolumn{6}{|c|}{ 2001: 1} \\
\hline \multicolumn{5}{|c|}{ Number of Articles published by Rev Bras Cir Cardiovasc: } & \multicolumn{6}{|c|}{$2001: 42$} \\
\hline \multicolumn{5}{|l|}{ Immediacy Index } & \multicolumn{3}{|c|}{$(1 / 42)=$} & \multicolumn{3}{|c|}{0.0238} \\
\hline \multicolumn{5}{|c|}{ Total Scielo Citations to Rev Bras Cir Cardiovasc: } & \multicolumn{6}{|l|}{57} \\
\hline $\begin{array}{l}2001 \text { citations to } \\
\text { Publications in: }\end{array}$ & 2001 & 2000 & 1999 & 1998 & 1997 & 1996 & 1995 & 1994 & 1993 & 1992 \\
\hline Citations/year: & 1 & 3 & 9 & 11 & 13 & 5 & 3 & 2 & 2 & 2 \\
\hline \% acumulated: & 1.8 & 7.0 & 22.8 & 42.1 & 64.9 & 73.7 & 78.9 & 82.5 & 86.0 & 89.5 \\
\hline \multicolumn{8}{|l|}{ Half-Life } & \multicolumn{3}{|l|}{4.35} \\
\hline
\end{tabular}

Table 2. REVISTA BRASILEIRA DE CIRURGIA CARDIOVASCULAR citing other journals in 2001. Only Journals that received more than 20 citations are listed.

\begin{tabular}{|l|l|l|l||}
\hline POSITION & CITATIONS & $\begin{array}{l}\text { JOURNAL } \\
\text { DATA } \\
\text { BASE CITED }\end{array}$ & JOURNAL \\
\hline \hline $1 / 189$ & 166 & ISI & $\begin{array}{l}\text { JOURNAL OF THORACIC AND } \\
\text { CARDIOVASCULAR SURGERY }\end{array}$ \\
\hline $2 / 189$ & 120 & ISI & ANNALS OF THORACIC SURGERY \\
\hline $3 / 189$ & 103 & ISI & CIRCULATION \\
\hline \hline $4 / 189$ & 49 & SciELO & $\begin{array}{l}\text { REVISTA BRASILEIRA DE CIRURGIA } \\
\text { CARDIOVASCULAR }\end{array}$ \\
\hline $5 / 189$ & 32 & ISI & AMERICAN JOURNAL OF CARDIOLOGY \\
\hline \hline $6 / 189$ & 29 & ISI & $\begin{array}{l}\text { EUROPEAN JOURNAL OF CARDIO-THORACIC } \\
\text { SURGERY }\end{array}$ \\
\hline \hline $7 / 189$ & 27 & ISI & $\begin{array}{l}\text { JOURNAL OF THE AMERICAN COLLEGE } \\
\text { OF CARDIOLOGY }\end{array}$ \\
\hline $8 / 189$ & 20 & ISI & JOURNAL OF CARDIAC SURGERY \\
\hline
\end{tabular}

articles published by each author in ISI-indexed journals was, therefore, 6.47. Besides, 102 (47\%) authors have contributed articles to ISI-indexed journals. These data show beyond any doubt that the authors of Rev. Bras. Cir. Cardiovasc. articles are frequent contributors to the mainstream of the scientific literature.

\section{1 - SciELO General Coordinator}

\section{2 - SciELO Operational Coordinator, Director of BIREME}

